\title{
논문 2013-08-12
}

\section{다중 안테나 기반 위상 차이를 이용한 $\mathrm{AOA}$ 측위 기법}

\author{
(Multi-Antenna based AOA Positioning using Phase \\ Difference)
}

\author{
박 익 현, 유 국 열, 박 용 완 \\ (Ik-Hyun Park, Kook-Yeol Yoo, Yongwan Park)
}

\begin{abstract}
In this paper, we have studied the performance of the AOA (Angle of Arrival) in multi-antenna systems for LBS (Location Based Services) and we also analyzed the performance of the AOA in SISO (Single Input Single Output) in multipath environments and their differences. The adequacy of AOA positioning in new communication environments was determined. Currently used positioning methods in 3G communication environment has been developed based on SISO. However, the accuracy of SISO-based TOA (Time of Arrival), TDOA (Time Difference of Arrival), AOA positioning techniques degraded in multipath environments. The communication system will be changed and developed. According to enhanced positioning techniques are required. Using antenna characteristics and the phase difference between antennas of LTE-Advanced standard's key technique MIMO system AOA positioning, and SISO based AOA positioning performance were analyzed. We found that AOA technique potential for use based on Multiple antenna systems by computer simulations.
\end{abstract}

Keywords : LBS, Multi-antenna, SISO, MIMO, AOA, Phase difference

\section{I. 서 론}

현재 위치 기반 서비스는 주로 GPS(Global Position System)과 이동통신 망을 이용하여 이동 단말기의 위치 정보를 획득한다. GPS는 위성의 신 호를 수신 받아 위치 측위를 함으로써 다른 시스템 에 비해 월등히 좋은 위치 정보를 제공한다. 그러나 $\mathrm{GPS}$ 의 신호는 추가적인 장치를 필요로 하고, 물체 에 대한 투과성이 좋지 못함으로 도심이나 실내 환 경에서는 정확한 위치 정보를 제공하지 못한다. 이

* Corresponding Author (ywpark@yu.ac.kr) Received: 16 July 2012, Revised: 28 Aug. 2012, 24 Dec. 2012, Accepted: 10 Jan. 2013.

I.H. Park, K.Y. Yoo, Y.W. Park: Yeungnam University

※ 본 논문은 2012년도 정부(교육과학기술부)의 재원으로 한국연구재단의 지원을 받아 수행된 기 초 연구사업임(No. 2012-015596)

※ 본 논문은 2010년 영남대학교 교비 지원을 받 아 수행되었음(과제번호 : 210-A-251-089) (c) J. IEMEK 2013 April: 8(2) 95-102 ISSN : 1975-5066
동통신 망을 이용한 방식은 현재 여러 가지 기법을 기반으로 GPS 기반 방식의 단점을 어느 정도 해결 하여 주지만 Multi-path, NLOS(Non Line of Sight)로 인한 전파 지연으로 인한 위치 측위 오차 를 가지게 된다.

주로 사용되는 네트워크 기반의 위치측위 기법 으로는 기지국 반경 셀을 이용한 Cell ID 기법, 두 개 이상의 기지국으로부터 전송된 신호의 방향으로 방위각을 측정하여 단말기의 위치를 구하는 $\mathrm{AOA}$ (Angle Of Arrival)기법, 세 개의 기지국으로부 터 전송되는 신호의 전송시간을 이용하는 TOA(Time of Arrival)기법, 기지국으로부터의 전 송시간의 차이를 이용하는 TDOA(Time Difference of Arrival)기법 등이 있다 [1, 2]. Cell ID 기법은 셀 반경에서 멀어질수록 위치측위 정확도가 크게 감소한다. TOA, TDOA 방식은 전파 지연으로 인한 시간의 변화에 민감하기 때문에 멀티패스 환경에서 정확도가 감소하게 된다. $\mathrm{AOA}$ 방식은 $\mathrm{NLOS}$ 에 의 한 방위각의 변화로 인해 오차가 발생하며, 이는 단 말기와 기지국 사이의 거리가 멀어질수록 더 심해 
진다 [3-5].

이러한 단점을 보완하기 위해 현재 3 세대 이동 통신 시스템에서는 위치측위 시 패턴매칭 알고리즘 을 주로 사용하고 있다. 패턴매칭 알고리즘은 신호 의 전파 특성을 측정된 위치와 함께 데이터베이스 로 구축하고, 위치측위 요청 시 수신 신호의 전파 특성과 데이터베이스를 비교하여 위치를 측위 하는 방식이다. 그러나 이러한 패턴매칭 알고리즘은 위치 측위 전에 반드시 데이터베이스가 구축 되어 있어 야 하며, GPS 신호 음영지역에서는 데이터베이스를 구축할 수 없는 문제점이 있는 등 데이터베이스 의 존도가 높은 방식이다 $[6,7]$.

이러한 네트워크 기반의 위치측위는 현재 3 세대 이동통신 환경 하에서 이루어지고 있다. 그러나 앞 으로의 이동통신 환경은 WiBro, LTE-Advanced 등 4세대 이동통신으로 바뀌게 될 것이다. 이에 따 라, 위치 기반 서비스의 기반이 되는 통신 환경과 기술이 변하게 되고 그에 따른 위치측위 각 기법들 의 성능 또한 변하게 될 것이다. 4 세대 이동통신 환 경의 핵심기술로는 MIMO(Multi Input Multi Output), OFDM(Orthogonal Frequency Division Multiplexing), Smart Antenna 등이 있다. 위치측 위의 측면에서 $\mathrm{MIMO}$ 는 단말기와 기지국에 설치된 다수의 안테나를 통한 공간 다중화(spatial diversity)를 바탕으로 멀티패스 환경에 강건한 성 능을 가져올 것으로 생각된다. $\mathrm{OFDM}$ 은 CDMA(Code Division Multiple Access)에 비해 크 게 줄어든 칩 길이로 인해 멀티패스로 인한 전송시 간 오차가 위치측위에 미치는 영향이 감소될 것으 로 생각된다. 이처럼 변화된 이동통신 환경에서 정 확한 위치측위를 위해서는 환경에 맞는 적절한 위 치측위 기법을 사용하는 것이 중요하다.

본 논문에서는 $\mathrm{MIMO}$ 시스템에서의 위치측위를 위하여 안테나 특성과 밀접하게 관련이 있는 $\mathrm{AOA}$ 기법의 성능을 분석하고, $\mathrm{AOA}$ 기법의 위치측위 성 능을 향상시키기 위해 안테나 간 위상 차이를 이용 한 수신 각도 측정 알고리즘을 이용하여 멀티패스 환경에서 기존의 $\mathrm{AOA}$ 기법에 비해 강건한 성능을 가지는 다중 안테나 시스템 기반 안테나 간 위상 차이를 이용한 $\mathrm{AOA}$ 기법을 제안하고자 한다.

\section{II. 기존의 $\mathrm{AOA}$ 측위 기법}

네트워크 기반의 위치 측위 기법 중 하나인 $\mathrm{AOA}$ 는 각 기지국들로부터 전송된 신호의 방향을

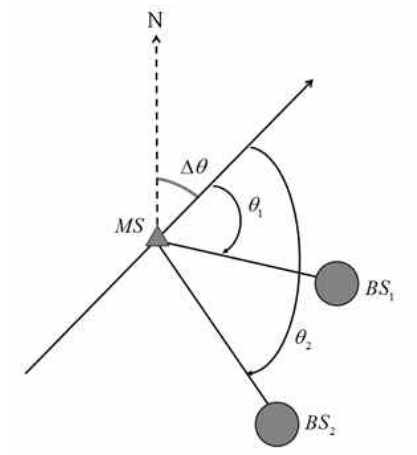

그림 1. 오리엔테이션 정보를 이용한 수신각도

Fig. 1 Received angle using orientation information

측정하여 방위각을 구하고, 이것을 이용하여 단말기 의 위치를 추정하는 방식이다. AOA기법은 오리엔 테이션 정보를 이용하여 수신 각도를 구하고 위치 를 추정한다. 오리엔테이션 정보는 북쪽으로부터 시 계방향으로의 각도로 정의된다. $\mathrm{AOA}$ 측정을 얻기 위한 일반적인 한가지 방법은 각 기지국에서 안테 나 배열을 사용하는 것이다. 다른 방법은 기지국으 로 전송되는 신호들 간의 각도를 측정하는 방법이 다 [8].

그림 1 에서 각도 $\theta_{1}$ 과 $\theta_{2}$ 는 각각 모바일 $\mathrm{MS}$ 에 서 측정된 기지국 에서 송신된 신호의 상대적인 $\mathrm{AOA}$ 이다. 모바일의 오리엔테이션 정보를 $\triangle \theta$ 로 가 정하면, 기지국 $B S_{1}, B S_{2}$ 로부터의 $\mathrm{AOA}$ 는 다음 식 과 같이 된다.

$$
\left(\theta_{i}+\triangle \theta\right)(\bmod 2 \pi), i=\{1,2\}
$$

각각의 완전한 $\mathrm{AOA}$ 측정에 일치하는 기지국에 서 시작되는 신호를 따라 모바일의 위치는 결정된 다. 모바일 MS는 두 개 이상의 일직선이 아닌 기지 국이 있을 때, 모든 신호의 교점에 위치한다.

그림 2 에서 각도 $\angle B S_{1} M S B S_{2}, \quad \angle B S_{1} M S B S_{3}$, $\angle B S_{2} M S B S_{3}$ 는 완전한 $\mathrm{AOA}$ 를 사용하여 계산할 수 있다. 모든 각은 같은 현에서 동일하게 범위가 정해 진다. 그러므로, 두 기지국과 그들이 만나는 현, 고 정된 각도에 의해 원의 호가 정해지고 세 번째 위 치의 범위가 그 호로 결정된다. 모바일 MS는 각도 $\angle B S_{1} M S B S_{2}$, 현 $B S_{1}, B S_{2}$ 에 의해 결정된 $B S_{1}, M S, B S_{2}$ 를 지나는 호에 위치하게 된다. 이러한 $\mathrm{AOA}$ 기법들은 기지국과 모바일 사이의 LOS를 필요 로 한다. 멀티패스 환경에서는 NLOS에 의해 $\mathrm{AOA}$ 측정이 어려워지고 그에 따라 위치 측위에 오차가 


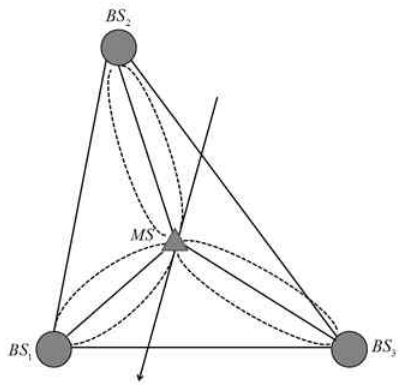

그림 2. 수신 각도를 이용한 $\mathrm{AOA}$ 측위

Fig. 2 AOA positioning using received angle

발생하게 된다. 이러한 오차는 모바일과 기지국 간 의 거리가 멀어질수록 더욱 커지게 되어 위치 측위 의 성능을 떨어트리게 된다[9-11].

\section{III. 제안하는 $A O A$ 측위 성능 향상 기법}

다중 안테나의 특성을 이용하면 또 다른 $\mathrm{AOA}$ 위치측위가 가능하다. 다수의 안테나를 가지는 레이 더 시스템에서는 안테나 간의 위상, 진폭 등의 차이 를 이용하여 수신 각도를 측정하는 기법이 널리 활 용되고 있다. 이러한 기법을 네트워크 기반의 $\mathrm{AOA}$ 측위 기법에 적용하여 측위 성능을 향상시키는 기 법을 제안한다. 다중 안테나 시스템에서 각각의 안 테나에 수신되는 신호는 안테나 사이의 거리에 따 른 전송 딜레이를 가지게 된다. 이러한 딜레이로 인 해 각각의 안테나에 수신되는 신호의 진폭, 위상 등 이 변화하게 된다. 이때, 각각의 안테나에 수신되는 위상 차이를 이용하여 신호의 수신각도를 추정할 수 있다. 이렇게 추정된 수신각도를 이용하여 $\mathrm{AOA}$ 위치측위가 가능하게 된다.

그림 3은 안테나 간 위상 차이를 이용한 수신 각도 계산 방법에 대해 나타낸 것이다. 여기서 $\mathrm{d}$ 는 안테나 사이의 거리를 나타내며, $\theta_{1}$ 은 전파의 수신 각도를 나타낸다. 안테나 $V_{1}$ 과 $V_{2}$ 사이의 $2 \pi$ 에 의 해 정규화된 위상 차이를 $\tau$ 로 표기하고, 식(2)와 같 이 나타낼 수 있다.

$$
\tau=f T_{0}
$$

여기서 $f$ 는 신호의 주파수, $T_{0}$ 는 delay time을 나타낸다. Delay time은 delay distance를 빛의 속 도로 나눈 값과 같다. Delay distance는 삼각함수 의 공식을 이용하여 $d \sin \theta_{1}$ 으로 나타낼 수 있다. 이

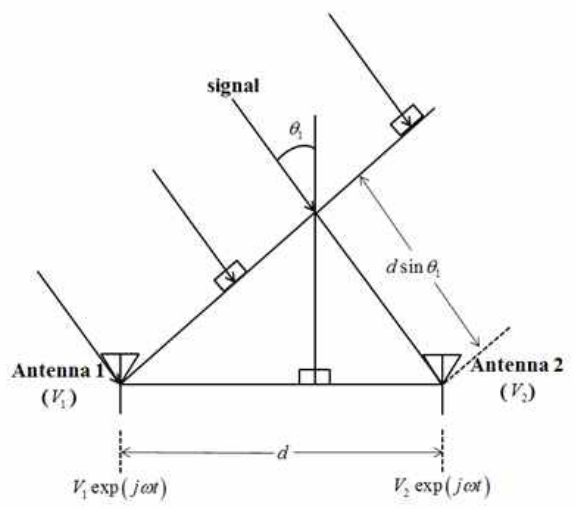

그림 3. 안테나 간 위상 차이를 이용한 수신 각도 추정

Fig. 3 Received angle estimation using phase difference between antenna

를 이용하면 delay time을 식(3)으로 표현할 수 있 다.

$$
T_{0}=\frac{d \sin \theta_{1}}{C}
$$

여기서 $\mathrm{C}$ 는 빛의 속도를 나타낸다. 식(3)을 이용 하여 안테나 간 위상 차이를 식(4)로 표현할 수 있 다.

$$
\tau=\frac{f\left(d \sin \theta_{1}\right)}{C}
$$

식(4)를 이용하여 안테나 간 위상 차이를 이용하 여 수신 각도를 계산할 수 있게 되며, 이를 역으로 전개하여 식(5)와 같이 표현할 수 있다.

$$
\theta_{1}=\arcsin \left(\frac{\tau C}{f d}\right)
$$

안테나 간 위상 차이를 측정할 수 있을 경우, 이 를 $\tau_{\text {estimate }}$ 로 표현하여 식(5)에 적용할 경우 수신 각도를 측정할 수 있으며 식(6)과 같이 표현할 수 있다. 여기서 $\theta_{\tau}$ 는 안테나 간 위상 차이를 이용하여 새롭게 측정한 수신 각도를 나타낸다.

$$
\theta_{\tau}=\arcsin \left(\frac{\tau_{\text {estimate }} C}{f d}\right)
$$

이를 통해 다중경로로 인해 변하게 되는 수신 각도를 알아낼 수 있게 되고 이를 이용하여 $\mathrm{AOA}$ 측 위가 가능해진다. $\mathrm{AOA}$ 측위 기법은 다중경로로 인 한 수신 각도의 변화에 민감하여 작은 각도 변화에 도 측위 오차가 커지는 단점이 있다 [12]. 그러나 다중경로 환경에서 신호의 위상 변화는 각도 변화 에 비해 적다. 그러므로 위상 차이를 이용해 수신 


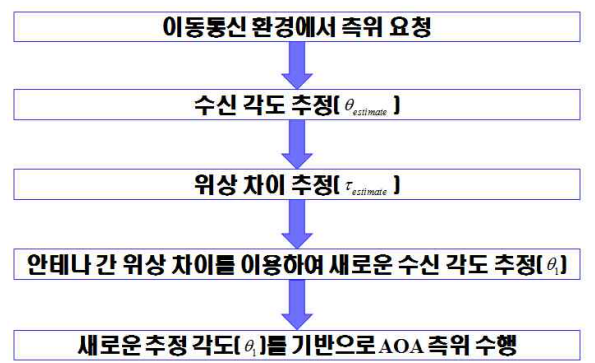

그림 4. 알고리즘 흐름도

Fig. 4 Algorithm flow chart

각도를 추정하여 $\mathrm{AOA}$ 측위 시 측위 오차가 감소할 것이다. 또한, 위상 추정을 통한 위상 오차를 보정 하는 것이 가능하다. 따라서, 다중경로 환경에서 $\mathrm{AOA}$ 측위 시 정확성을 높일 수 있을 것이다[9].

이렇듯 다중 안테나 시스템의 특성을 이용하면 기존의 방식과는 다른 $\mathrm{AOA}$ 위치 측위가 가능하다. 다중 안테나 시스템에서 각각의 안테나에 수신되는 신호는 안테나 사이의 전송 경로에 따른 전송 딜레 이를 가지게 된다. 이러한 딜레이로 인해 각각의 안 테나에 수신되는 신호의 진폭, 위상 등 신호의 정보 가 다르게 된다. 이때, 각각의 안테나에 수신되는 위상의 차이를 이용하여 신호의 수신 각도를 계산 할 수 있고 이러한 수신 각도 계산을 통해 다중경 로로 인해 변하게 되는 수신 각도를 알아낼 수 있 게 되고 이를 이용하여 $\mathrm{AOA}$ 위치 측위가 가능하게 된다.

$\mathrm{AOA}$ 위치 측위 기법은 다중경로로 인한 수신 각도의 변화에 민감하여 작은 각도 변화에도 위치 측위 오차가 증가하는 단점이 있다. 그러나 다중경 로 환경에서 신호의 위상 변화는 각도 변화에 비해 그 폭이 적기 때문에 위상 차이를 이용하여 수신 각도를 계산할 경우 $\mathrm{AOA}$ 위치 측위 시 측위 오차 가 감소하게 된다. 또한, 위상 추정을 통한 위상 오 차를 보정하는 것이 가능하고 따라서 다중경로 환 경에서 $\mathrm{AOA}$ 위치 측위 시 정확성을 크게 향상시킬 수 있을 것으로 예상된다.

다음 그림 4 는 제안하는 알고리즘의 과정을 보 여준다.

\section{IV. 시뮬레이션 결과}

\section{1. 실험 환경}

$\mathrm{AOA}$ 기법의 경우 기본적으로 $\mathrm{LOS}$ 신호 성분을 가정하고 있기 때문에 가장 먼저 수신되는 신호를
LOS성분으로 판단하고 이러한 신호의 수신 각도를 이용해 위치 측위를 한다. 실제 환경에서는 다중경 로, NLOS 등으로 인해 수신 각도가 변하게 되고 이러한 점이 위치 측위 시 오차를 야기하게 된다. 이러한 점을 바탕으로 LOS 신호의 수신 각도와 위 상을 평균값으로 가지는 가우시안 분포로 수신 각 도와 위상을 변화시켜 시뮬레이션을 진행하였다. 가 우시안 분포의 분산을 변화시켜 수신 각도 및 위상 의 변화에 따른 위치 측위 오차에 대해 실험하였다. 가우시간 분포에 따라 LOS 성분의 수신 각도와 위 상을 평균으로 두고 분산을 유의구간으로 설정하여 분산 값을 10 에서 0.5 까지 변경하며 시뮬레이션을 진행하였다. 각각의 분산 값에 따라 각 1000 번씩의 시뮬레이션 진행 후 그 평균을 구하고 이에 대한 $\mathrm{CDF}$ 를 표현하였다. 각 기법에 대한 측위 테스트는 아래와 같은 과정으로 진행하였다.

(1) 수신각도 $\theta_{\text {estimate }}$ 의 분산 값을 10 으로 하여 수 신각도 오차누적분포함수를 구한다.

(2) 수신위상차이 $\tau_{\text {estimate }}$ 의 분산 값을 10 으로 하여 수신각도를 계산한다 $\theta_{\tau}$.

(3) $\theta_{\tau}$ 와 원 수신각도를 비교하여 오차누적분포함수 를 구한다.

(4) 수신각도와 수신 위상차이의 분산값을 변화시키 며 원 수신각도와의 오차를 비교한다.

(5) 분산값을 0.5 씩 변화시키며 $\theta_{\text {estimate }}$ 와 $\theta_{\tau}$ 를 기 반으로 각각의 $\mathrm{AOA}$ 기법을 수행한다.

(6) 각 기법의 시뮬레이션결과를 비교하여 측위 정 확도에 대해 분석한다.

실험에 대한 개요는 표 1 과 같고, 각 기법에 대 한 실험은 그림 5 와 같은 과정으로 진행하였다.

\section{2. 시뮬레이션 결과}

시뮬레이션 결과는 분산 값의 변화를 기준으로 성능을 분석하였다. 제안하는 알고리즘은 분산 값의 크기에 따라서 그 성능이 다르게 나타난다. 다르게 말하면 수신 신호의 분산 값이 클수록 기존의 SISO 기반의 $\mathrm{AOA}$ 기법의 위치 측위 결과와 차이가 많이 난다. 이러한 차이는 분산 값이 작을수록 LOS 성분 을 많이 포함하고 있어 각도의 변화가 크지 않다는 것을 의미하며, 반대로 $\operatorname{LOS}$ 성분이 많이 포함되지 않은 신호일 때 기존의 기법과 성능의 차이가 크게 나타난다. 또한 분산 값이 너무 크게 적용될 경우 신호의 수신각도 및 위상이 너무 크게 변하게 되어 
표 1. 테스트 파라미터

Table 1. Test Parameters

\begin{tabular}{|c|c|}
\hline 측위 기법 & SISO AOA, MIMO AOA, using phase difference AOA \\
\hline 수신 각도 $\left[\theta_{\text {estmaxe }}\right]$ & Gaussian distribution, mean : $\theta_{0}$, var : $0.5 \sim 10$ \\
\hline 수신 위상 $\left[\tau_{\text {estmate }}\right]$ & Gaussian distribution, mean $: \tau_{0}$, var $: 0.5 \sim 10$ \\
\hline 수신국 안테나 수 & 2 \\
\hline 기지국 수 & 3 \\
\hline 안테나간 거리 & $\lambda / 2$ \\
\hline 기지국 간 거리(m) & 1000 \\
\hline 반복 웟수 & 1000 \\
\hline
\end{tabular}

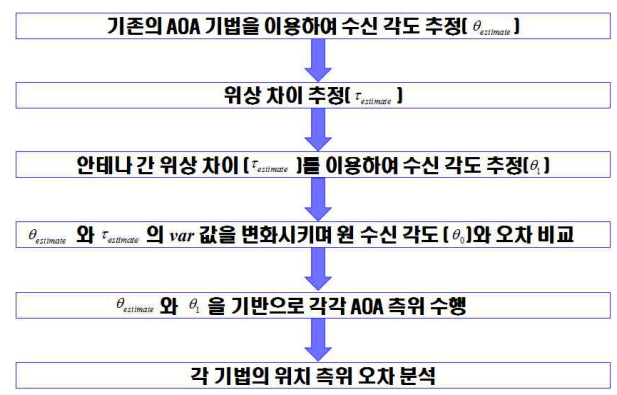

그림 5. 테스트 과정

Fig. 5 Test process

결국 위치 측위 시 큰 오차를 야기하게 된다.

이러한 이유로 모든 분산 값에 대해 위치 측위 오차를 줄이는 효과를 나타내지는 않는다. 제안 기 법은 분산 값이 일정수준으로 크거나 환경적인 요 소로 인해 LOS 성분과 차이가 나는 수신각도 및 위상을 가질 경우, 이러한 값이 미치는 영향을 줄이 기 위한 방법으로 사용된다. 그러므로 이 장에서는 분산 값에 따른 제안 알고리즘과 기존 알고리즘의 차이에 대해 분석한다.

그림 6 은 각 기법의 수신 각도 추정 오차에 대 한 누적분포함수를 나타낸 것이다. $\mathrm{x}$ 축은 수신 각도 오차, $\mathrm{y}$ 축은 오차의 누적확률을 의미한다. 이를 통 해 수신 신호의 분산 값의 변화에 따라 수신 신호 에 큰 변화가 생기는 경우 제안하는 기법이 기존의 기법에 비해 수신 각도의 오차가 작다는 것을 확인 할 수 있다. 이러한 작은 수신 각도의 오차는 $\mathrm{AOA}$ 기법을 이용한 측위 시 더 강건한 성능을 가질 수 있을 것이다.

그림 7은 기존 알고리즘과 제안 알고리즘을 적 용하였을 때의 측위 오차를 누적분포함수로 나타낸

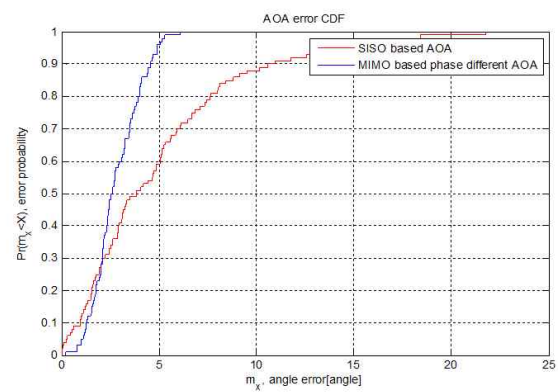

그림 6. 각도 에러에 대한 누적분포함수 $(\operatorname{var}=10)$

Fig. 6 Cumulative Distribution Function of angle error(var=10)

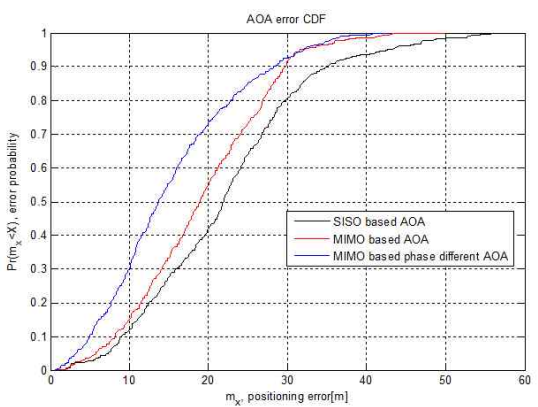

그림 7. 측위 오차에 대한 누적분포함수 $(\operatorname{var}=10)$

Fig. 7 Cumulative Distribution Function of positioning error(var=10)

것이다. $\mathrm{x}$ 축은 측위 오차 $(\mathrm{m}), \mathrm{y}$ 축은 측위 오차의 누 적확률을 의미한다. 위 실험의 경우 SISO 기반의 $\mathrm{AOA}$ 기법의 경우 평균적으로 약 $23 \mathrm{~m}$ 의 위치 측위 오차나 나타났으며, $\mathrm{MIMO}$ 기반의 $\mathrm{AOA}$ 기법의 경 우 약 $21 \mathrm{~m}$, 위상 차이를 이용한 수신 각도 측정 기 법의 경우 평균 오차가 약 $15 \mathrm{~m}$ 로 나타났다. 이를 토대로 분산 값의 변화에 따라 수신 신호의 변화가 클 경우 제안 기법이 기존의 기법에 비해 위치 측 위 시 더 강건한 성능을 나타내는 것을 확인할 수 있다.

그림 8의 경우, 분산 값을 작게 적용하였을 경우 각 기법의 측위 오차의 누적분포함수를 나타낸 그 림이다. 분산 값이 아주 작게 적용될 경우에는 앞에 서 설명한 것처럼 성능이 크게 개선되지 않음을 확 인할 수 있다. 분산 값이 작게 적용되는 경우 수신 신호가 LOS 성분을 많이 포함하고 있어 기존 기법 의 오차가 작음을 알 수 있다. 최대 오차는 기존 기 법과 제안 기법이 거의 차이가 없지만 평균 오차는 기존 기법이 약 $1 \sim 2 \mathrm{~m}$ 정도 작게 나타나는 것을 확 


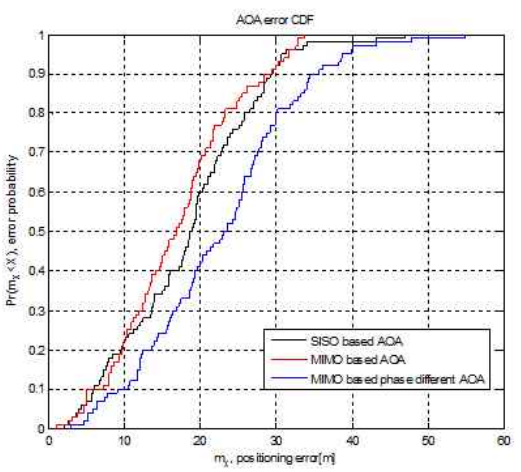

그림 8. 측위 오차에 대한 누적분포함수 $(\operatorname{var}=1)$

Fig. 8 Cumulative Distribution Function of positioning error(var=1)

인할 수 있다. 이는 분산 값이 작은 경우 수신 신호 에 LOS 성분이 많이 포함되어 있고, 결국 LOS를 토대로 위치 측위를 하는 $\mathrm{AOA}$ 기법의 특성 상 수 신 각도를 정확하게 계산할 수 있게 되는 이는 결 국 위치 측위 시 오차가 작게 나타나게 된다.

반대로 그림 9 의 경우, 분산 값을 일정 수준 이 상 크게 적용하였을 경우의 측위 오차를 나타낸 그 림이다. 분산 값이 크게 적용될 경우에는 수신 신호 가 LOS 신호와 큰 차이를 나타내게 되고 결국 수 신 각도를 정확하게 계산하지 못하게 되어 위치 측 위 시 오차를 야기하게 된다. 이러한 경우 SISO 기 반의 $\mathrm{AOA}$ 기법에 비해 제안 기법이 최대 오차 및 평균 오차가 약 $8 \mathrm{~m}$ 정도 작게 나타나는 것을 확인 할 수 있다. 이를 통해, 수신 신호가 환경에 의해 변화가 심할 경우에는 제안 기법의 위치 측위 성능 이 더 강건하다는 것을 알 수 있다.

결론적으로 $\mathrm{MIMO}$ 시스템 기반 안테나 간 위상 차이를 이용한 $\mathrm{AOA}$ 기법은 기존의 기법보다 평균 $8 \mathrm{~m}$ 정도의 측위 정확도 향상을 나타내었다. 또한, 분산 값이 5 이하일 때 가장 높은 측위 정확도를 나 타내었다. 또한 분산 값이 커질수록 오차가 점점 커 지고 기존 기법과 성능의 차이가 점점 없어진다. 이 러한 현상은 다양한 환경을 모두 고려해야 하는 특 성 상 위치 측위 정확도를 감소시킬 수 있다. 분산 값이 7 이상인 경우, 위치 측위 정확도가 크게 감소 하며, 분산 값이 증가할수록 점점 더 정확도가 감소 하였다. 이는 다양한 채널 환경의 특성 상 분산 값 이 증가할수록 수신 각도를 정확하게 계산하지 못 하게 되고, 결국 $\mathrm{AOA}$ 기법의 측위 정확도를 떨어 트려 오차를 야기하게 된다. 결론적으로 제안 기법

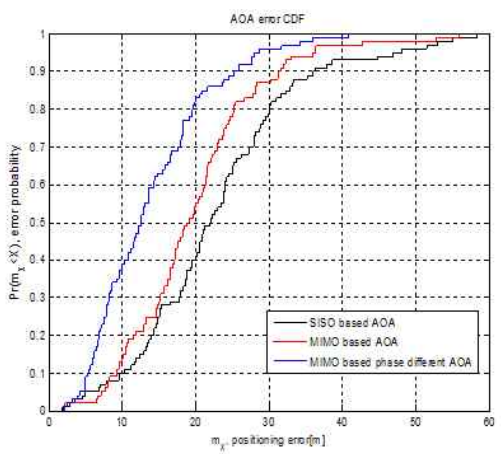

그림 9. 측위 오차에 대한 누적분포함수(var=5)

Fig. 9 Cumulative Distribution Function of positioning error(var=5)

의 성능은 분산 값이 1 이하일 경우 가장 높은 측 위 정확도를 나타내었으며, 분산 값이 3 5 사이일 경우 기존 기법에 비해 측위 정확도가 더 향상된다. 이를 통해 멀티패스 환경에서 멀티 안테나 시스템 기반의 안테나 간 위상 차이를 이용한 $\mathrm{AOA}$ 기법의 성능을 검증하였다.

\section{V. 결 론}

본 논문에서는 멀티 안테나 시스템 기반에서 $\mathrm{AOA}$ 기법의 위치 측위 오차를 줄이기 위한 안테나 간 위상 차이를 이용한 $\mathrm{AOA}$ 기법을 제시하였다. 선행적으로 $\mathrm{AOA}$ 기법의 오차를 분석하고 수신 신 호가 변화하는 환경에서 실험을 통해 검증하는 과 정을 나타내었다. 수신 각도가 변화하는 멀티패스 환경에서 수신 각도 변화로 인한 $\mathrm{AOA}$ 기법의 위치 측위 오차를 보완하기 위해서 위상 차이를 이용한 수신 각도 계산 및 이를 이용한 $\mathrm{AOA}$ 기법을 제안 하였다. 세부적으로 분산 값을 변화시키며 수신 신 호의 각도 및 위상 변화에 대한 성능을 실험하고 오차를 경감시키고자 하였다. 제안 기법을 이용한 시뮬레이션 결과 기존의 기법을 적용했을 때보다 좀 더 향상된 결과를 나타냈다. 기존 기법에 비해 약 $8 \mathrm{~m}$ 의 위치 측위 정확도가 향상되었다.

그러나 $\mathrm{AOA}$ 기법의 특성 상 분산 값이 매우 큰 환경, 달리 말해 수신 신호의 각도 변화가 매우 심 한 환경에서는 위치 측위 성능 향상을 얻기가 어렵 다. 따라서 이러한 환경에서 오차를 경감할 수 있는 기법에 대한 연구가 진행되어야 한다. 이를 위해서 는 수신 각도의 오차를 줄이는 것보다 변화된 위상 
값을 channel estimation을 통해 보완을 하여 위상 오차를 줄이는 것이 가장 좋은 성능을 나타낼 것으 로 예상된다. 위상 오차를 보완하는 동시에 다양한 측위 기법의 정확도 향상 알고리즘을 병행한다면 좀 더 향상된 측위 정확도를 이끌어낼 수 있을 것 이다.

\section{참고문헌}

[1] N.J. Thomas, D.G.M. Cruickshank, D.I. Laurenson, "Performance of A TDOA-AOA Hybrid Mobile Location System," Proceedings on 3G Mobile Communication Technologies, pp.216-220, 2001

[2] E. Trevisani, A. Vitaletti, “Cell-ID location technique, limits and benefits: an experimental study," Proceesings on IEEE Workshop of Mobile Computing Systems and Applications, pp.51-60, 2004.

[3] W. Sean, "Angle of Arrival Estimation using Received Signal Strength with Directional Antennas," Engineering Honors Theses, 2010.

[4] C. Mensing, S. Plass, "Positioning Algorithms for Cellular Networks Using TDOA," Proceedings on IEEE Acoustics, Speech and Signal, Vol.5, pp.513-516, 2006.

[5] E.K.L. Hung, R.W. Herring, "Comparisons of Error Characteristics between TOA and TDOA Positioning," IEEE Transactions on Acoustics, Speech, Signal Processing, Vol. 29, No. 5, pp.1084-1089, 1981.

[6] T.N. Lin, P.C. Lin, "Performance comparison of indoor positioning techniques based on location fingerprinting in wirelessnetworks," Proceedings on WIRLES'05, Vol. 2, pp.1469-1574, 2005.

[7] B. Li, J. Barnes, C. Rizos, D. Li, "Probabilistic Algorithm to Support the Fingerprinting Method for CDMA Location," Proceedings on GPS/GNSS, pp.8-10, 2005.

[8] I. Park, Y. Park, "MIMO Based AOA Positioning with Phase Difference in Multipath Environments," Proceedings on ISET, 2011.

[9] R. Peng, M.L. Sichitiu, "Angle of Arrival Localization for Wireless Sensor Networks,"
Proceedings on Sensor and AdHoc Communications and Networks, pp.374-382, 2006.

[10] D. Niculescu, B. Nath, "Ad Hoc Positioning System (APS) Using AOA," Proceesings on Annual Joint Conference of the IEEE Computer and Communications, pp.1734-1743, 2003.

[11] K. Kobayashi, T. Someya, T. Ohtsuki, S.P.W. Jarot, T. Kashima, "MIMO System with Relative Phase Difference Time-Shift Modulation in Rician Fading Environments," IEICE Transaction on Communications, Vol. E91.B, No. 2, pp.459-465, 2010.

[12] Q.H. Spencer, B.D. Jeffs, M.A.Jensen, A.L. Swindlehurst, "Modeling the Statistical Time and Angle of Arrival Characteristics of an Indoor Multipath Channel," IEEE Journal of Selected Areas in Communications, Vol. 18, No. 3, pp.347-360, 2002. 


\section{저 자 소 개}

\section{박 익 현}

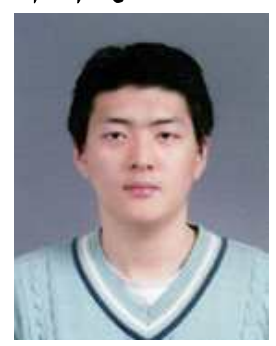

Email: ihpark82@gmail.com

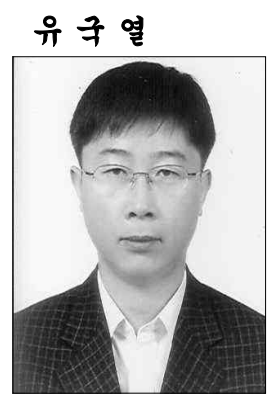

1991년 경북대학교 전자 공학과 학사.

1993년 한국과학기술원 전기및전자학과 석사.

1998년 한국과학기술원 전기및전자학과 박사.

1998년 8월 2001년 3월 삼성전자 중앙연 구소 책임연구원.

현재, 영남대학교 정보통신공학과 교수 관심분야: 멀티미디어통신, 영상압축, 영상 처리

Email:kyoo@yu.ac.kr

\section{박 용 완}

1982년 경북대 전자공학

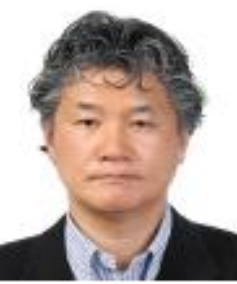
과 학사.

1984년 경북대 전자공 학, 뉴욕주립대 전기공학 과 석사.

1992년 뉴욕주립대 전기 공학과 박사.

1992년 10월 1993년 12월 California Institute of Technology Research Fellow. 1994년 1월 1996년 8월 SK Telecom 기술개발 부장.

2003년 1월 2004년 1월 UC Irvine 방문 교수.

2008년 1월 2009년 12월 IEEE VTS 한 국지회 위원장.

현재, 영남대 정보통신공학과 교수, (사)임베 디드공학회 부학회장.

관심분야: 이동통신, 무선멀티미디어 설계기 술, 텔레매틱스, 차세대 위치기반 기술.

Email:ywpark@yu.ac.kr 